\title{
Effects of maternal nicotine on breastfeeding infants
}

\author{
Efeitos da nicotina materna na criança em amamentação
}

Efecto de la nicotina en el niño en amamantación

Cândida Caniçali Primo, Priscilla Bôa F. Ruela², Léia Damasceno de A. Brotto , Telma Ribeiro Garcia ${ }^{4}$ Eliane de Fátima Lima ${ }^{5}$

\section{ABSTRACT}

Objective: To assess scientific evidence about the effects of maternal nicotine on infant by an integrative review.

Data sources: Studies published in Portuguese, English and Spanish, from 1990 to 2009, with abstracts available in the Latin American Health Sciences Literature (Lilacs) and Medical Literature Analysis and Retrieval System On-Line (Medline) databases. The descriptors were: "breastfeeding", "lactation" and "smoking".

Data synthesis: The main identified effects of nicotine on infants were: changes in sleep and wakefulness patterns; reduction of iodine supply; hystopathological damage on liver and lung; intracellular oxidative damage; reduction of pancreatic $\beta$ cells; and decreased glucose tolerance.

Conclusions: It is recommended to inform mothers about harmful chemicals contained in cigarettes that can be secreted into breast milk. They should be strongly encouraged to stop smoking during lactation.

Key-words: breast feeding; lactation; smoking.

\section{RESUMO}

Objetivo: Avaliar as evidências científicas sobre efeitos da nicotina materna na criança em amamentação, a partir de uma revisão integrativa.

Fontes de dados: Artigos publicados em português, inglês e espanhol, de 1990 a 2009, com resumos disponíveis nas bases Literatura Latino-Americana em Ciências da Saú-

Instituição: Universidade Federal do Espírito Santo (UFES), Vitória, ES, Brasil 'Mestre em Saúde Coletiva pela UFES; Professora do Curso de Graduação e Mestrado Profissional em Enfermagem da UFES, Vitória, ES, Brasil

${ }^{2}$ Enfermeira pela UFES, Vitória, ES, Brasil

${ }^{3}$ Doutoranda em Enfermagem da Universidade Federal do Rio de Janeiro (UFRJ); Professora do Curso de Enfermagem da UFES, Vitória, ES, Brasil ${ }^{4}$ Doutora em Enfermagem pela Universidade Federal da Paraíba (UFPB); CoDiretora do Centro para Pesquisa e Desenvolvimento da CIPE ${ }^{\circledR}$ do Programa de Pós-Graduação em Enfermagem da UFPB, João Pessoa, PB, Brasil ${ }^{5}$ Doutoranda em Enfermagem da UFRJ; Professora do Curso de Graduação e Mestrado Profissional em Enfermagem da UFES, Vitória, ES, Brasil de (Lilacs) e Medical Literature Analysis and Retrieval System On-Line (Medline). Utilizaram-se os descritores: "aleitamento materno", "lactação" e "tabagismo".

Síntese dos dados: Os principais efeitos da nicotina encontrados para a criança foram alterações nos padrões de sono e vigília; redução da oferta de iodo; danos histopatológicos no fígado e no pulmão; danos oxidativos intracelulares; redução de células $\beta$ do pâncreas; e diminuição da tolerância à glicose.

Conclusões: Recomenda-se que as mães sejam informadas sobre os produtos químicos prejudiciais contidos no cigarro, os quais passam para o bebê por meio do leite materno, devendo ser fortemente encorajadas a não fumar durante a lactação.

Palavras-chave: aleitamento materno; lactação; hábito de fumar.

\section{RESUMEN}

Objetivo: Evaluar las evidencias científicas sobre efectos de la nicotina materna en el niño en amamantación, a partir de una revisión integrativa.

Fuentes de datos: Artículos publicados en portugués, inglés y español, de 1990 a 2009, con resúmenes disponibles en las bases Literatura Latinoamericana en Ciencias de la Salud (Lilacs) y Medical Literature Analysis and Retrieval System On-Line (Medline). Se utilizaron los descriptores: «lactancia materna», «lactancia» $\mathrm{y}$ «tabaquismo».

Síntesis de los datos: Los principales efectos de la nicotina encontrados fueron alteraciones en los estándares de sueño y vigilia; reducción de la oferta de yodo; daños histopatológicos en el hígado y en los pulmones; daños

\author{
Endereço para correspondência: \\ Cândida Caniçali Primo \\ Rua João de Oliveira Soares, 241/701 - Jardim Camburi \\ CEP 29090-390 - Vitória/ES \\ E-mail: candidaprimo@gmail.com \\ Conflito de interesse: nada a declarar
}

Recebido em: 24/8/2012

Aprovado em: 23/4/2013 
oxidativos intracelulares; reducción de células $\beta$ del páncreas y reducción de la tolerancia a la glucosa.

Conclusiones: Se recomienda que las madres sean informadas sobre los productos químicos perjudiciales contenidos en los cigarrillos, que pasan para el bebé mediante la lactancia materna, debiendo ser fuertemente motivadas a no fumar durante la gestación y lactancia.

Palabras clave: lactancia materna; lactancia; hábito de fumar.

\section{Introduction}

Breastfeeding is recognized as the most appropriate way of providing ideal food to meet the nutritional needs of all children and promoting optimal growth and development. More than 200 substances are found in breast milk composition, among which the following stand out: water, carbohydrates, proteins, lipids, minerals and vitamins, as well as cellular immunological components (macrophages, lymphocytes, neutrophils, and epithelial cells) and soluble components (immunoglobulins A, G, M, D and E, complement system, interleukins 6,8 and 10, cytokines, bifid factor, resistance factor, lactoferrin, antioxidants, and hormones such as insulin, erythropoietin, bombesin, thyroxine, among others ${ }^{(1)}$.

Breastfeeding is beneficial to the child, to the mother, to the family, and also to society. As for the child, the following aspects stand out: reduction of infant mortality, especially from diarrhea and respiratory infections; reduction of allergic manifestations; improvement in neuropsychomotor development; reduction of the incidence of chronic diseases, such as arterial hypertension, diabetes mellitus, Crohn disease, ulcerative colitis, celiac disease, autoimmune diseases, and lymphoma; protective action against dental problems such as dental occlusion, mouth breather syndrome, and speech articulation disorders ${ }^{(2)}$.

For the mother, the act of breastfeeding accelerates the process of uterine involution, due to the release of oxytocin; reduces postpartum bleeding and thus the chances of developing anemia; decreases the occurrence of diabetes mellitus, of cancers (breast, ovarian and uterine) and of bone fractures due to osteoporosis; promotes mother-child bonding; has a contraceptive effect on newly delivered mothers, increasing the time interval between pregnancies; and promotes greater postpartum weight loss in women who breastfeed exclusively for six months or more. For the family, it saves money, avoiding expenses with infant formulas, feeding bottles, and medication for the baby, since exclusively breastfed babies will be healthier ${ }^{(1,2)}$.

Although being aware of the many benefits of breastfeeding, experts are concerned about maternal smoking when it comes to the children, since they may be exposed both to cigarette smoke (second-hand smoker) and to nicotine transferred via breast milk. The consequences of passive exposure to smoke for children are well defined in the literature: worsening and development of allergic diseases, such as rhinitis and asthma ${ }^{(3)}$, onset of chronic respiratory illnesses ${ }^{(4)}$, increased duration and frequency of upper and lower airway infections ${ }^{(5)}$, and greater frequency of hospitalizations ${ }^{(6)}$.

However, the possible effects on the child, resulting from the transfer of the harmful components of cigarettes via breast milk, such as cyanide, aluminum, dichlorodiphenyltrichloroethane (DDT), arsenic, ammonia, formaldehyde, benzene, lead, hydrogen, carbon monoxide and dioxide, and especially nicotine ${ }^{(7)}$, are not well elucidated yet, with little evidence showing adverse effects on breastfed infants ${ }^{(8)}$.

Studies indicate the risks arising from maternal smoking: reduction of basal prolactin levels and consequent decrease in milk supply ${ }^{(8,9)}$, changes in milk composition and fla$\operatorname{vor}^{(10)}$, and trend to early weaning ${ }^{(9,11)}$. In addition, more recent statistics indicate that $12-15 \%$ of women continue to smoke during pregnancy ${ }^{(8)}$. However, a study conducted in southern Brazil found a smoking prevalence of $23.5 \%$ during pregnancy ${ }^{(11)}$.

In view of the foregoing, this study aimed to assess evidence available in the literature about the effects of nicotine on breastfed infants.

\section{Method}

This is an integrative review that allows for the synthesis of relevant studies published on the topic, as well as promoting improvement in clinical practice and decision-making. It consisted of the following steps: identification of the theme and formulation of the research question; establishment of the objective of the review; establishment of inclusion and exclusion criteria for selection of articles; definition of the information to be extracted from the selected articles; evaluation of the studies included in the integrative review; interpretation and presentation of research results ${ }^{(12)}$.

The leading question was: what evidence is available in the literature about the effects of maternal nicotine on breastfed infants? A bibliographical survey was performed in the Latin American Health Sciences Literature (Lilacs) and Medical 
Literature Analysis and Retrieval System On-Line (Medline) databases. The descriptors used were: "breastfeeding", "lactation" and "smoking". Inclusion criteria were: articles published in Portuguese, English and Spanish, from 1990 to 2009; abstracts available in the databases; published studies whose methodology allowed us to obtain evidence, i.e., randomized controlled clinical trials in animals or studies with experimental or quasi experimental design in humans. Due to the low number of articles on the topic in human beings, it was necessary to include studies conducted in animals. It is also important to highlight that, although the study period covers the 1990's, no articles addressing the objective of this review were found in this period.

A total of 1,605 articles were identified in the two databases. After reading of the abstracts, 31 studies on the topic were selected and, among these, five dealt specifically with the effect of maternal nicotine on breastfed infants or offspring of animals, meeting the inclusion criteria. Of the articles selected, two of them were found in the Lilacs database and three in the Medline database.

\section{Results}

Five articles ${ }^{(13-17)}$ that met the pre-established inclusion criteria were identified and analyzed. The analysis and subsequent synthesis of the articles included in this review allowed for the elaboration of two charts, covering the following items: title of the article, with reference to its publication in the literature; objective(s) of the study; results and conclusions and/or recommendations. Chart 1 shows the two studies involving human beings; Chart 2, the three studies involving animals.

\section{Discussion}

Nicotine secreted into breast milk has a potential to cause severe adverse effects on the newborn ${ }^{(9)}$, which depends on the number of cigarettes consumed by the mother per day and also on the time interval between the last inhaled cigarette and the beginning of breastfeeding ${ }^{(18)}$, because the half-life of nicotine in breast milk is of approximately two hours ${ }^{(19)}$. Nicotine is rapidly absorbed by the intestine of the infant and may be accumulated in some tissues, causing episodes of apnea, restlessness and even vomiting ${ }^{(20)}$, because there is no knowledge of the exact period when infants develop the ability of completely metabolizing nicotine. It is known that, in a aqueous solution, nicotine is widely metabolized by the liver before reaching systemic circulation ${ }^{(18)}$, which, besides causing concern, deserves further studies ${ }^{(14,16)}$.

When investigating urinary cotinine levels in infants of smoking mothers and the contribution of breastfeeding to these values, researchers found that breastfeeding increases considerably the exposure to tobacco products, especially nicotine. This same study states that it is possible that the adverse effects of smoking on children, attributed only to environmental exposure to tobacco smoke by inhalation, are greatly influenced by breastfeeding, i.e., these effects are a consequence both of exposure by environmental inhalation and of exposure via breast milk ${ }^{(18)}$.

Chart 1 - Synthesis of the articles included in the integrative review - studies in human beings

\begin{tabular}{|c|c|c|c|}
\hline Title of the article & Objective(s)/method & Results & $\begin{array}{l}\text { Conclusions/ } \\
\text { recommendations }\end{array}$ \\
\hline $\begin{array}{l}\text { Breastfeeding and } \\
\text { smoking: short-term } \\
\text { effects on infant } \\
\text { feeding and sleep }{ }^{(13)}\end{array}$ & $\begin{array}{l}\text { To determine how } \\
\text { breastfeeding from a mother } \\
\text { who smokes affects infants } \\
\text { in the short term. } \\
\text { Experimental study. }\end{array}$ & $\begin{array}{l}\text { Children spent less time } \\
\text { sleeping immediately after their } \\
\text { mothers smoked ( } 53.4 \text { minutes), } \\
\text { compared with the day when } \\
\text { their mothers abstained from } \\
\text { smoking ( } 84.5 \text { minutes). }\end{array}$ & $\begin{array}{l}\text { An acute episode of smoking } \\
\text { by lactating mothers alters } \\
\text { the sleep/wake patterns of } \\
\text { breastfed infants. }\end{array}$ \\
\hline $\begin{array}{l}\text { lodine nutrition in } \\
\text { breast-fed infants } \\
\text { is impaired by } \\
\text { maternal smoking }\end{array}$ & $\begin{array}{l}\text { To assess the risk of iodine } \\
\text { deficiency in breasted infants } \\
\text { associated with maternal } \\
\text { smoking. } \\
\text { Experimental study. }\end{array}$ & $\begin{array}{l}\text { Smoking was associated with } \\
\text { reduction of breast milk iodine } \\
\text { content to nearly a half. Serum } \\
\text { thiocyanate levels were higher } \\
\text { in mothers who smoke. }\end{array}$ & $\begin{array}{l}\text { It is recommended that } \\
\text { breastfeeding mothers } \\
\text { should not smoke, but } \\
\text { if they do, additional } \\
\text { iodine supplementation is } \\
\text { suggested. }\end{array}$ \\
\hline
\end{tabular}


Studies indicate that the amount of nicotine found in breast milk is 2.9 times greater than that found in maternal blood plasma ${ }^{(21)}$ and that the amount of cotinine, the major metabolite of nicotine, present in the urine of infants breastfed by smoking mothers was on average ten times higher than that found in bottle-fed children whose mothers smoke. Urinary cotinine levels in infants breastfed by smoking mothers is similar to those found in adult smokers ${ }^{(18)}$.

As for the objective of this review, it was observed that the effects of maternal nicotine on infants are multiple, such as changes in sleep and wake patterns; reduction of iodine supply to the infant through breast milk, leading to an increased risk of deficiency of iodine and thyroid stimulating hormone (TSH); damage to the liver and lung, besides showing significantly higher levels of superoxide dismutase (SOD), minor catalase (CAT) and malondialdehyde (MDA); reduction of pancreatic $b$ cells responsible for insulin production and thus decrease in glucose tolerance; high body weight after weaning; hyperleptinemia; lower amount of type- 1 deiodinase in the liver. Generally speaking, articles recommend breastfeeding mothers to quit smoking.
As for changes in sleep and wake patterns ${ }^{(13)}$, a considerable change was observed in sleep and wake patterns when children were breastfed immediately after their mother smoked, with a variation from 53.4 minutes when their mothers smoked to 84.5 minutes when they did not. The authors attribute the reduction of the amount of time spent in active and quiet sleep to an acute episode of smoking by mothers. The study indicates that an acute episode of smoking significantly alters the sleep and wake patterns of breastfed infants. Corroborating these findings, another study observed that infants of smoking mothers have sleeping disorders ${ }^{(10)}$. It is also known that the inhaled nicotine causes problems for the infant, speculating that it could lead to irritability, excessive crying, lassitude, colic and pallor ${ }^{(5,7-10)}$.

As for iodine supply through breast milk ${ }^{(14)}$, it was described that breast milk iodine content was reduced in smoking mothers $(26.0 \mathrm{~g} / \mathrm{L})$ compared with nonsmoking mothers $(53.8 \mathrm{~g} / \mathrm{L})$; therefore, the amount of iodine found in the urine of infants was also similar to that of mothers: babies of smoking mothers had 33.3 versus $50.4 \mathrm{~g} / \mathrm{L}$ for children

Chart 2 - Synthesis of the articles included in the integrative review - studies in animals

\begin{tabular}{|c|c|c|c|}
\hline Title of the article & Objective(s)/ Method & Results & $\begin{array}{l}\text { Conclusions/ } \\
\text { Recommendations }\end{array}$ \\
\hline $\begin{array}{l}\text { Effects of maternal } \\
\text { nicotine exposure during } \\
\text { lactation on breast-fed rat } \\
\text { pups }^{(15)}\end{array}$ & $\begin{array}{l}\text { To investigate the effects } \\
\text { of maternal nicotine } \\
\text { exposure on rat pups } \\
\text { during lactation. } \\
\text { Experimental study. }\end{array}$ & $\begin{array}{l}\text { Maternal nicotine exposure } \\
\text { causes detrimental } \\
\text { histopathological changes } \\
\text { in the lung and liver of } \\
\text { lactating offspring and } \\
\text { induces oxidative stress. }\end{array}$ & $\begin{array}{l}\text { It recommended to inform } \\
\text { mothers about harmful } \\
\text { chemicals in cigarettes, which } \\
\text { are secreted into breast milk, } \\
\text { and to encourage them to stop } \\
\text { smoking during pregnancy and } \\
\text { lactation. }\end{array}$ \\
\hline $\begin{array}{l}\text { Fetal and neonatal } \\
\text { nicotine exposure } \\
\text { and postnatal glucose } \\
\text { homeostasis: identifying } \\
\text { critical windows of } \\
\text { exposure }^{(16)}\end{array}$ & $\begin{array}{l}\text { To identify critical } \\
\text { windows of fetal and } \\
\text { neonatal exposure to } \\
\text { maternal nicotine on } \\
\text { the development of } \\
\text { pancreatic } \beta \text { cell and } \\
\text { glucose intolerance in the } \\
\text { offspring of rats. } \\
\text { Experimental study. }\end{array}$ & $\begin{array}{l}\text { Continued exposure to } \\
\text { nicotine from conception } \\
\text { through lactation results } \\
\text { in permanent } \beta \text {-cell loss } \\
\text { and subsequent impaired } \\
\text { glucose tolerance. There } \\
\text { may be a recovery with } \\
\text { smoking cessation. }\end{array}$ & $\begin{array}{l}\text { Smoking cessation is } \\
\text { recommended during } \\
\text { pregnancy and lactation as } \\
\text { a way of preventing possible } \\
\text { permanent damage to } \beta \text { cells. }\end{array}$ \\
\hline $\begin{array}{l}\text { Short- and long-term } \\
\text { effects of maternal } \\
\text { nicotine exposure } \\
\text { during lactation on body } \\
\text { adiposity, lipid profile, } \\
\text { and thyroid function of rat } \\
\text { offspring }^{(17)}\end{array}$ & $\begin{array}{l}\text { To evaluate the } \\
\text { short- and long-term } \\
\text { consequences of } \\
\text { maternal nicotine } \\
\text { exposure, during lactation } \\
\text { on a rat offspring at } \\
\text { different ages. } \\
\text { Experimental study. }\end{array}$ & $\begin{array}{l}\text { Nicotine causes a neonatal } \\
\text { thyroid dysfunction } \\
\text { neonatal and programs } \\
\text { for significant adiposity, } \\
\text { hyperleptinemia, and } \\
\text { secondary hypothyroidism } \\
\text { in adulthood. }\end{array}$ & $\begin{array}{l}\text { It is concluded that lactation } \\
\text { is a critical period in which } \\
\text { nicotine may program for } \\
\text { obesity, with hypothyroidism } \\
\text { being a possible contributing } \\
\text { factor. }\end{array}$ \\
\hline
\end{tabular}


of nonsmoking mothers. The transfer of iodine into breast milk was negatively correlated to cotinine concentration in mother's urine. Cotinine is the most precise indicator of smoking status (half-life of approximately 20 hours). For the authors, this reduction of breast milk iodine content exposes the infant to an increased risk of iodine deficiency and may lead to physiological disorders in the child, since, during the period of breastfeeding, thyroid function of the infant depends on iodine in maternal milk. Another finding was that smoking mothers had significantly higher serum levels of thiocyanate, which may competitively inhibit the sodium-iodide symporter (secondary active transport, when two substances are transported in the same direction) responsible for iodide transport in the lactating mammary gland.

A study in rats ${ }^{(17)}$ found that maternal nicotine exposure imprints a neonatal thyroid dysfunction and possible secondary hypothyroidism in adulthood. This hypofunction was confirmed by the lower liver deiodinase 1 (or iodine peroxidase) activity in offspring exposed to nicotine at 15 and 180 days of life, since this enzyme activity is considered a marker of thyroid status, which is decreased in hypothyroidism and increased in hyperthyroidism. It was also observed that maternal nicotine exposure did not alter offspring body weight gain during lactation. However, after weaning, offspring exposed to nicotine showed higher body weight compared with the control offspring. The treatment with nicotine also caused hyperleptinemia at all ages tested (15, 21, 90 and 180 days), with significant increase at 180 days of life, i.e., in adulthood. During exposure in lactation (under 15 days of age) and in adulthood (180 days), the group exposed to nicotine showed higher total adiposity (27 and $33 \%$ ). In addition, it presented increased total body protein and visceral fat compared with controls. Lipid profile was not changed in adulthood.

Corroborating the results of both articles that addressed the negative effects of nicotine, with reduction of iodine supply to the infant through breast milk ${ }^{(14,17)}$, another research indicates decreased iodine supply in breast milk as a problem arising from smoking ${ }^{(9)}$.

As for increase in body weight after maternal nicotine exposure $^{(17)}$, the authors state that maternal smoking during lactation is a risk factor for obesity, because it contributes to the possibility of developing hypothyroidism. Epidemiological studies also indicate that maternal smoking may be related to childhood obesity, but all the related factors have not been elucidated yet ${ }^{(22,23)}$. As for hyperleptinemia, a significant increase was observed in adulthood, as well as a decrease in thyroid hormones ${ }^{(17)}$. Confirming these findings, a study describes that leptin is responsible for regulating food intake, increase in energy expenditure, neuroendocrine function and for helping in glucose and fat metabolism, besides reporting that the decrease in thyroid hormones leads to an increase in leptin levels ${ }^{(24)}$.

When investigating the effects of maternal nicotine during lactation of rat pups ${ }^{(15)}$, experts observed histopathological changes in the liver of the nicotine-exposed group, with portal inflammatory infiltrate, degeneration of hepatocytes, and focal necrosis in the parenchyma. Thickening of alveolar walls because of interstitial inflammation was noted in the lungs. In the experimental group, SOD levels were significantly lower compared with the control group (smokers: 24.82U/mg; nonsmokers: $34.89 \mathrm{U} / \mathrm{mg}$ ), as well as CAT levels (smokers: 532.32.10 $\mathrm{U} / \mathrm{mg}$; nonsmokers: $712.22 .10^{4} \mathrm{U} / \mathrm{mg}$ ), but MDA levels were significantly higher compared with the control group (smokers: $3.87 \mathrm{mmol} / \mathrm{mg}$; nonsmokers: $2.42 \mathrm{mmol} / \mathrm{mg}$ ). These results indicate that nicotine maternal exposure induces oxidative stress and causes histopathological impairment in the lung and liver of lactating offspring, since enzymes such as SOD and CAT, which act by sweeping away free radicals, are found at decreased levels; MDA, an important parameter of intracellular oxidative stress, is found to be high.

It was also demonstrated that nicotine exposure during pregnancy and lactation resulted in the permanent loss of pancreatic $\beta$ cells and subsequent impaired glucose tolerance $^{(16)}$. However, using nicotine only during lactation or only during pregnancy did not result in permanent damage, because animals exposed to nicotine only during pregnancy had reduced $\beta$ cell mass at birth. Exacerbated proliferation following nicotine weaning led to recovery to $98 \%$ with regard to controls (9.66mg compared with $9.83 \mathrm{mg}$ ). As for glucose homeostasis, the group exposed to nicotine during pregnancy and lactation had a greater response to the administered glucose load than the control group, showing decreased glucose tolerance at 26 weeks of age. This result is comparable to type- 2 diabetes model in humans. According to the authors, it is essential to consider the developmental differences between species, because in rats pancreatic development occurs both prenatally and postnatally, whereas, in humans, the majority of development is completed before term birth. These authors reaffirm the importance of quitting smoking during pregnancy and lactation as a way of preventing permanent damage that is likely to occur as a consequence of this habit. 
Generally speaking, studies recommend that mothers should be informed about harmful chemicals contained in cigarettes that can be secreted into breast milk and should be strongly encouraged to stop smoking during pregnancy and lactation. There is evidence proving the protective effect of breastfeeding on the incidence of respiratory diseases, even in children of smoking mothers ${ }^{(25)}$. Because the benefits of breast milk outweigh the risks of nicotine exposure, mothers should be advised to stop smoking during breastfeeding ${ }^{(13)}$.

Finally, this integrative review allows us to conclude that there is scientific evidence about the adverse effects of maternal nicotine on breastfed infants. These effects are of different nature, such as changes in sleep and wake patterns; reduction of iodine supply to the infant through breast

\section{References}

1. Brasil - Ministério da Saúde. Secretaria de atenção à saúde - departamento de atenção básica. Saúde da criança: nutrição infantil - Aleitamento materno e alimentação complementar. [Série A. Normas e Manuais Técnicos. Cadernos de Atenção Básica $n^{\circ}$ 23]. Brasília: Ministério da Saúde, 2009.

2. Carvalho MR, Tamez RN. Amamentação: bases científicas para a prática profissional. Rio de Janeiro: Guanabara Koogan; 2002.

3. Weitzman M, Gortmaker S, Walker DK, Sobol A. Maternal smoking and childhood asthma. Pediatrics 1990;85:505-11.

4. Mannino DM, Siegel M, Husten C, Rose D, Etzel R. Environmental tobacco smoke exposure and health effects in children: results from the 1991 National Health Interview Survey. Tob Control 1996;5:13-8.

5. Stoddard JJ, Miller T. Impact of parental smoking on the prevalence of wheezing respiratory illness in children. Am J Epidemiol 1995;141:96-102.

6. Jin C, Rossignol AM. Effects of passive smoking on respiratory illness from birth to age eighteen months, in Shanghai, People's Republic of China. J Pediatr 1993;123:553-8.

7. Einarson A, Riordan S. Smoking in pregnancy and lactation: a review of risks and cessation strategies. Eur J Clin Pharmacol 2009;65:325-30.

8. Del Ciampo LA, Almeida CA, Ricco RG. Passive smoking in early life. Pediatria (São Paulo) 1999;21:15-20.

9. Matheson I, Rivrud GN. The effect of smoking on lactation and infantile colic. JAMA 1989;261:42-3.

10. Hill PD, Aldag JC. Smoking and breastfeeding status. Res Nurs Health 1996;19:125-32.

11. Kaufmann CC, Albernaz EP, Silveira RB, Silva MB, Mascarenhas ML. Feeding during the first three months of life for infants of a cohort in Pelotas, Rio Grande do Sul, Brazil. Rev Paul Pediatr 2012;30:157-65.

12. Galvão CM, Sawada NO, Trevizan MA. Systematic review: a resource that allows for the incorporation of evidence into nursing practice. Rev Latino-Am Enfermagem 2004;12:549-56.

13. Mennella JA, Yourshaw LM, Morgan LK. Breastfeeding and smoking: short-term effects on infant feeding and sleep. Pediatrics 2007;120: 497-502. milk, with increased risk of iodine and TSH deficiency; histopathological damage in the liver and lung; intracellular oxidative damage; reduction of pancreatic $\beta$ cells; decreased glucose tolerance; increased body weight after weaning from maternal addiction, and hyperleptinemia.

Given the negative effects of the nicotine present in breast milk on the infant, it is recommended that mothers should be informed about all the harmful chemicals contained in cigarettes that can be secreted into breast milk. They should be strongly encouraged to stop smoking during pregnancy and lactation. More investigations are needed to analyze the physiological effects of tobacco smoke and nicotine during breastfeeding in terms of breast milk production, neonatal hormone levels, child's weight gain, child's behavior, and breastfeeding time.

14. Laurberg P, Nøhr SB, Pedersen KM, Fuglsang E. lodine nutrition in breast-fed infants is impaired by maternal smoking. J Clin Endocrinol Metab 2004;89:181-7.

15. Ozokutan BH, Ozkan KU, Sari I, Inanç F, Güldür ME, Kilinç M. Effects of maternal nicotine exposure during lactation on breast-fed rat pups. Biol Neonate 2005;88:113-7.

16. Bruin JE, Kellenberger LD, Gerstein HC, Morrison KM, Holloway AC. Feta and neonatal nicotine exposure and postnatal glucose homeostasis: identifying critical windows of exposure. J Endocrinol 2007;194:171-8.

17. Oliveira E, Moura EG, Santos-Silva AP, Fagundes AT, Rios AS, Abreu-Villaça $Y$ et al. Short- and long-term effects of maternal nicotine exposure during lactation on body adiposity, lipid profile, and thyroid function of rat offspring. J Endocrinol 2009;202:397-405.

18. Mascola MA, Van Vunakis H, Tager IB, Speizer FE, Hanrahan JP. Exposure of young infants to environmental tobacco smoke: breast-feeding among smoking mothers. Am J Public Health 1998;88:893-6.

19. Schulte-Hobein B, Schwartz-Bickenbach D, Abt S, Plum C, Nau H. Cigarette smoke exposure and development of infants throughout the first year of life: influence of passive smoking and nursing on cotinine levels in breast milk and infant's urine. Acta Paediatr 1992;81:550-7.

20. Luck W, Nau H. Nicotine and cotinine concentrations in serum and milk of nursing smokers. Br J Clin Pharmacol 1984;18:9-15.

21. Amir LH. Maternal smoking and reduced duration of breastfeeding: a review of possible mechanisms. Early Hum Dev 2001;64:45-67.

22. Toschke AM, Koletzko B, Slikker W Jr, Hermann M, von Kries R. Childhood obesity is associated with maternal smoking in pregnancy. Eur $\mathrm{J}$ Pediatr 2002;161:445-8.

23. Widerøe M, Vik T, Jacobsen G, Bakketeig LS. Does maternal smoking during pregnancy cause childhood overweight? Paediatr Perinat Epidemiol 2003;17:171-9.

24. Romero CE, Zanesco A. The role of leptina and ghrelin on the genesis of obesity. Rev Nutr 2006;19:85-91.

25. Woodward A, Douglas RM, Graham NM, Miles H. Acute respiratory illness in Adelaide children: breast feeding modifies the effect of passive smoking. J Epidemiol Community Health 1990;44:224-30. 